\title{
Isolation and Characterization of Starch Degrading Rhizobacteria
}

\section{Dida G*, Etisa D and Gizawu B \\ Microbial Biodiversity Directorate, Ethiopian Biodiversity Institute, Ethiopia}

*Corresponding author: Gudeta Dida, Microbial Biodiversity Directorate, Ethiopian Biodiversity Institute, P. O. Box 30726 Addis Ababa, Ethiopia, Email: gudetadida2014@gmail.com

\section{Research Article}

Volume 3 Issue 2

Received Date: July 20, 2018

Published Date: August 30, 2018

DOI: $10.23880 /$ oajmb-16000129

\section{Abstract}

Starch degrading bacteria are important for different industries such as food, fermentation, textile, and paper. The aim of this study is to isolate and characterize bacteria able to degrade starch from the rhizospheres of various plants at four sites located in Jimma University main campus. Collected soil samples were labeled as kobo (AJUMC), Avocado (BJUMC), Banana (CJUMC), and Cana indicia (DJUMC) respectively. Soil samples were serially diluted in sterilized peptone water; poured on sterilized starch agar plates, and incubated at $32^{\circ} \mathrm{C}$ for $48 \mathrm{~h}$. The representative colonies shown different morphology was randomly picked up using the streaking method on nutrient agar. A total of 53 bacterial isolates were obtained from the soils rhizospheres. Microscopic characteristics showed that, among the 53 isolates 38 (72\%) were Gram-positive bacteria, rod shaped, while 15(28\%) were Gram-negative rod shaped bacteria. Based on the biochemical tests, the results revealed that, the 38 isolates were belonging to the genera Bacillus while the remaining isolates were belonging to the genera Pseudomonas. All isolates were catalase positive and only 15 isolates (Pseudomonas) were KOH positive and were negative to grow at $80^{\circ} \mathrm{C}$, while the 38 (Bacillus) isolates have positive growth at $80^{\circ} \mathrm{C}$. The highest values of starch degrading index were the Gram positive bacteria isolates. The amylase activity was also carried with respect to time, temperature and $\mathrm{pH}$ of the media. The maximum activity of amylase at different temperatures from 35 to $45^{\circ} \mathrm{C}$ was recorded at $35^{\circ} \mathrm{C}(0.94 \mathrm{U} / \mathrm{ml})$ within $24 \mathrm{~h}$, while maximum activity at different pH from 5 to 9 was recorded at $\mathrm{pH} 7(1 \mathrm{U} / \mathrm{ml})$.

Keywords: Rhizobacteria; Starch degrading; Amylase enzyme; Bacillus; Pseudomonas

\section{Introduction}

The diversity of microbes is associated with plant roots $[1,2]$. The narrow zone of soil directly surrounding the root system is referred to as rhizosphere, while the term 'rhizobacteria' implies a group of rhizosphere bacteria competent in colonizing the root environment [3]. The rhizosphere is soil ecological environment for 
plant-microbe interactions involving colonization of different microorganisms in associative, symbiotic, naturalistic, or parasiticinte ractions depending upon plant nutrient status in soil, soil environment, and the type of microorganism proliferating in the rhizosphere zone. When microbes are close to epidermis, plants secrete signal molecules against invasive microbes in the root zone, consequently differentiation takes place between pathogenic, symbiotic, or naturalistic adaptation of microbes with the plant $[4,5]$.

Rhizosphere bacteria, especially species of Pseudomonas and Bacillus have been identified in the rhizosphere of various leguminous and non-leguminous [6,7]. Different bacterial genera are vital components of soils. They are involved in various biotic activities of the soil ecosystem to make it dynamic for nutrient turn over. Ahmad and Kibret [3] reported that based on the functional activities rhizo bacteria are classified as (i) bio fertilizers (increasing the availability of nutrients to plant), (ii) phytostimulators, (iii) Rhizoremediators (degrading organic pollutants), (iv) Biopesticides (controlling diseases, by production of different metabolites).

Various researches are formulated to develop biodegradable polymers as a waste management option for polymers. Biodegradable polymer is a degradation of polymer through the action of metabolism of microorganisms." Natural polymers (i.e., proteins, polysaccharides, nucleic acids, starch) are degraded in biological systems by oxidation and hydrolysis $[8,9]$. There are various starch degrading microorganisms from different sources [10-12]. Rhizospere is one sources of starch degrading microorganism as it contains mostly starch substrate.

Bacteria are tiny living organisms, also called microorganisms, so small they cannot be seen with the naked eye but can be observed using a microscope. They are believed to be the first life-form that emerged on earth. Starch degrading bacteria are very important in various industries such as food, fermentation, textile and paper. Thus isolating and manipulating pure culture from various sources; such as soil has manifold importance for various biotechnology industries [13].

Starch is a polysaccharide carbohydrate, that produced by green plants as a source of energy store and food for humans. It composed of large number of glucose units that linked together by glycoside bonds. Starch is one of the most industrial raw materials that can process into variety of products in different industries, ranging from food to washing detergent industries. The production of starch reaches several hundred million tons all over the world yearly and also important material in foods, paper manufacture, medicine, petroleum and well boring, plastics, fine chemicals, packing materials, and other manufacture industries [14].

Starch is one of the most abundant heterogeneous polysaccharide produced by plants in the form of water insoluble granules [15]. It is a polymeric carbohydrate, composed of carbon hydrogen, and oxygen atoms in the formula $\mathrm{Cx}\left(\mathrm{H}_{2} \mathrm{O}\right)_{\mathrm{y}}$ of hundreds or thousands of D-glucose repeating units. These units are linked together by acetal bonds formed between the hemiacetal carbon atom, C1, of the cyclic glucose structure in one unit and a hydroxyl group at either the C3 (amylose) or the C6 (for the branch units in amylopectin) atoms in the adjacent unit. The starch polymer, because of its complex structure, requires a combination of enzymes such as, endoamylases and exoamylases for the depolymerization of starch into its monomers, or to transform starch by transferring oligoglucosidic linkages and residues by the creation of new bonds (debranching enzymes and glycosyltransferases).

The enzymes commonly used for starch processing are generally classified as amylase. Starch has a vital role in the preparation of synthetic biodegradable polymer. Starch based biodegradable materials have the proven capability to decompose in the most common environment where the material is degraded through natural biological processes from polluting the environment [16]. The objective of the present study is to isolate and characterize the starch degrading bacteria from different soils rhizopheres of Jimma University.

\section{Materials and Methods}

\section{Description of Study Area}

The study was conducted at Jimma, located $353 \mathrm{~km}$ southwest of Addis Ababa, the capital city of Ethiopia. The town's geographical coordinates are $7041^{\prime} \mathrm{N}$ latitude, $36^{\circ} 50^{\prime} \mathrm{E}$ longitude, and an average altitude of $1,780 \mathrm{~m}$ above sea level. It lies in the climatic zone locally known as "Woyna Daga" (1,500-2,400 m above sea level) which is considered to be ideal for agriculture as well as human settlement. The town is generally characterized by warm climate with a mean annual maximum temperature of $30^{\circ} \mathrm{C}$ and a mean annual minimum temperature of $14^{\circ} \mathrm{C}$. The annual rain fall ranges from $1138-1690 \mathrm{~mm}$. The maximum precipitation occurs during the three months period from June through August, with minimum rainfall 
occurring in December and January. From a climatic point of view, abundant rain fall makes this region one of the best watered of Ethiopian highland areas, conducive for agricultural production) [17].

\section{Samples Collection}

Ten grams of soil were collected from the rhizopheres of various plants at four sites located in Jimma University. The soil sample were put in the sterilized bag and transferred immediately to the laboratory.

\section{Microbial Analyses}

Sample preparation and isolation of starch degrading bacteria: Each $10 \mathrm{~g}$ of soil samples from different site was mixed with $90 \mathrm{ml}$ of sterile peptone water in different $250 \mathrm{ml}$ beaker and homogenized in a flask for ten minutes using orbital shaker at $110 \mathrm{rpm}$. Subsequently, $1 \mathrm{ml}$ of each sample was transferred aseptically into $9 \mathrm{ml}$ of sterile peptone water and mixed thoroughly using vortex. The homogenates was serially diluted -up to $10^{-5}$, and then $0.1 \mathrm{ml}$ aliquot of appropriate dilution was spread properly on starch agar plates. The plate were incubated at $32^{\circ} \mathrm{C}$ for $48 \mathrm{~h}$ The bacterial isolates shown different colonies morphology were picked out and purified. A fourth gram of soil samples were collected from four different sites ( $10 \mathrm{~g}$ from each site) of Jimma university plant rooted by streaking on nutrient agar [18].

\section{Identification of bacterial isolates}

The bacterial isolates were subjected to identification using morphological characteristics such as Gram reaction and endospore formation. Biochemical tests included catalase test, $\mathrm{KOH}$ test, and the growth at $80^{\circ} \mathrm{C}$ were also performed.

KOH-test (Test for Lipopolysaccharide): Two drops of $3 \% \mathrm{KOH}$ solution were placed on a clean microscopic slide. Each colony was aseptically picked up from nutrient agar plates and stirred in the $\mathrm{KOH}$ solution for 1 minute. The inoculating loop was raised slowly from the mass, when the $\mathrm{KOH}$ solution become viscous, the thread of slime followed the loop for 0.5 to $2 \mathrm{~cm}$ or more in gramnegative bacteria. While addition of $\mathrm{KOH}$, there was no slime, but a watery suspension that do not follow the loop, the reaction was considered negative and the isolate was considered as gram positive bacteria.

Catalase Test: Catalase taste was carried out after young colonies flooded with a $3 \%$ solution of hydrogen peroxide $\left(\mathrm{H}_{2} \mathrm{O}_{2}\right)$. The formation of bubbles indicates positive catalase test.

\section{Determination of Starch Degrading Index (SDI)}

The ability of the bacterial isolates to degrade starch was described by the starch degrading index (SDI): the ratio of the total diameter of clear zone and colony diameter. On the basis of degrading index potential colonies with the best efficiency were selected as best starch degrading colonies.

Screening for Amylase Activity (Starch Iodine Test): Isolated strains were picked up from each plate containing pure culture and streaked in straight lines in starch agar plates as carbon source. The plates were incubated at $32^{\circ} \mathrm{C}$ for $48 \mathrm{~h}$. After incubation, the plates were flooded with (Gram's iodine- $250 \mathrm{mg}$ iodine crystals added to $2.5 \mathrm{gm}$ potassium iodide solution, and $125 \mathrm{ml}$ of distilled water, to produce a deep blue colored.

Amylase production: Amylase was produced by using complex medium containing starch $1.0 \%$, yeast extract $0.04 \%, \quad\left(\mathrm{NH}_{4}\right)_{2} \mathrm{HPO}_{4} 0.4 \%, \mathrm{KCl} 0.1 \%$ and $\mathrm{MgSO}_{4} 7 \mathrm{H}_{2} \mathrm{O}$ $0.05 \%$, and semisynthetic medium containing peptone $0.4 \%,\left(\mathrm{NH}_{4}\right)_{2} \mathrm{HPO}_{4} 0.4 \%$ and $\mathrm{KCl} 1.0 \%$.

Enzyme assay for amylase enzyme: A suitable volume of isolated broth culture was incubated for $48 \mathrm{~h}$ then was centrifuged at $5000 \mathrm{rpm}$ for $20 \mathrm{~min}$. at $4^{\circ} \mathrm{C}$. Supernatant was recovered. Amylase was determined using spectrophotometer. One milliliter of crude enzyme was placed into a test tube and $1 \mathrm{ml}$ of $1 \%$ soluble starch in sodium phosphate buffer $(\mathrm{pH} 7)$ was added into test tube. The test tubes were covered and incubate at $35^{\circ} \mathrm{C}$ for 10 min. Subsequently, $2.0 \mathrm{ml}$ DNS reagent was added in each tube to stop the reaction and kept in boiling water bath for $10 \mathrm{~min}$. After cooling at $25^{\circ} \mathrm{c}$ final volume was made to $10 \mathrm{ml}$ with distilled water. The absorbance was measured at $540 \mathrm{~nm}$ using spectrophotometer. A unit of amylase activity was defined as the amount of amylase required to catalyze the liberation of reducing sugar equivalent to $1 \mathrm{~mol}$ of $\mathrm{D}$-glucose per minute under the assay conditions.

\section{Determination of Different Parameters for Amylase}

Determination of pH: One percent of Starch was used as a substrate. Four sets of Substrate solution were prepared in sodium phosphate buffer with adjusted $\mathrm{pH}$ values 5,6 , 7,8 , and 9.1 milliliter of each of crude enzyme solution was added into buffer tubes. Mixture was incubated at $35^{\circ} \mathrm{C}$ for $10 \mathrm{~min}$, then $2 \mathrm{ml}$ of DNS reagent were added to terminate the reaction and the mixture was incubated in boiling water for $10 \mathrm{~min}$. After cooling at room temperature, final volume was made to $10 \mathrm{ml}$ with 
distilled water and the activity of the enzymes was measured based on the absorbance at 540 $\mathrm{nm}$.

Determination of optimum temperature: One $\mathrm{ml}$ of the substrate was distributed into six test tubes and $1 \mathrm{ml}$ of phosphate buffer pH 7 was added in each test tubes. Tubes were marked with different temperature (at 30, 35, $40^{\circ} \mathrm{C}$ ). $1 \mathrm{ml}$ of crude enzyme solution was added in each tube. Then tubes were incubated at specific temperature for 10 minutes. Reactions were terminated by adding $2 \mathrm{ml}$ DNS reagent and the mixture incubated in boiling water for $10 \mathrm{~min}$. After cooling at room temperature, final volume was made to $10 \mathrm{ml}$ with distilled water and the activity of enzymes were determined by taking the absorbance at $540 \mathrm{~nm}$.

Determination of optimum time: The effect of different time duration such as 24,48 , and $72 \mathrm{~h}$ on amylase activity was observed.

Determination of concentration of starch: Similarly to observe the effect of different substrate concentration on amylase activity, the dialyzed aliquot was added to different starch concentrations $(0.5,1.0,1.5$, and $2 \%)$ and the activity was observed following the method.

\section{Result and Discussion}

The morphology and biochemical tests resulted from 4 samples of Jimma University main campus plant roots of 53 isolates were summarized in Table 2 below. In the present study, On the basis their gram reaction, out of 53 isolates $38(72 \%)$ had rod shape gram positive bacteria while $15(28 \%)$ were gram negative rod shaped bacteria .All the gram negative were rod shaped, non-spore forming, similarly gram positive bacteria were rod shaped and spore former. Biochemically, 53 isolates were catalase positive, only 15 isolates were $\mathrm{KOH}$ test positive and other all isolates showed $\mathrm{KOH}$ negative (Table 1, 2 and 3) (Figure 1).

\begin{tabular}{|c|c|c|}
\hline Isolate code & No. of isolates & Plant rhizosphere \\
\hline AJUMC & 17 & Kobo \\
\hline BJUMC & 10 & Avocado \\
\hline CJUMC & 11 & Banana \\
\hline DJUMC & 15 & Cana indicia \\
\hline
\end{tabular}

Table 1: Total isolated colonies and their codes from 4 sites of Rhizobacteria (RB).

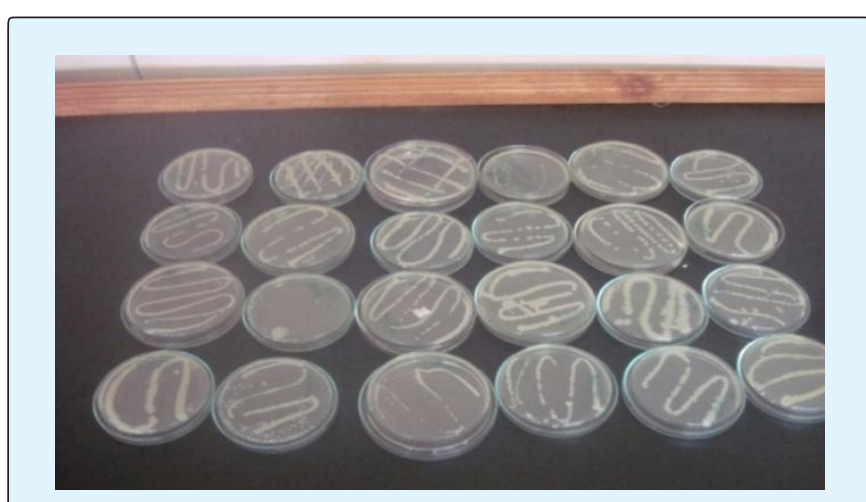

Figure 1: Morphology and Biochemical tests.

\begin{tabular}{|c|c|c|}
\hline \multicolumn{2}{|c|}{ Morphology of 53 isolates of bacteria } \\
\hline Cell shape & Rod & 53 \\
\hline \multirow{2}{*}{ Colony arrangement } & Chain & 41 \\
\hline \multirow{2}{*}{ Endospore } & Single bacillus & 12 \\
\hline \multirow{2}{*}{ Gram reaction } & + & 38 \\
\cline { 2 - 3 } & - & 15 \\
\cline { 2 - 3 } & + & 38 \\
\hline
\end{tabular}

Table 2: Morphological features of isolates of Rizobacteria.

\begin{tabular}{|c|c|c|c|c|c|c|}
\hline Isolate code & NO. of isolates & KOH test & Catalase test & Growth at $\mathbf{8 0}^{\circ} \mathbf{C}$ & Starch hydrolysis test & Identification \\
\hline AJUMC & 13 & - & + & + & + & Bacillus \\
\hline AJUMC & 4 & + & + & - & + & Pseudomonas \\
\hline BJUMC & 7 & - & + & + & + & Bacillus \\
\hline BJUMC & 3 & + & + & + & + & Pseudomonas \\
\hline CJUMC & 7 & - & + & - & + & Pacillus \\
\hline CJUMC & 4 & + & + & + & + & Bacillus \\
\hline DJUMC & 11 & - & + & - & + & Pseudomonas \\
\hline DJUMC & 4 & + & + & + & + & + \\
\hline
\end{tabular}

Table 3: Biochemical tests of isolated strains of Rhizobacteria (RB). 
Among the 53 isolates, 4 isolates were Gram-negative and 13 isolates were Gram-positive isolated from the rhizophere of kobo (A site) plant. Similarly, seven isolates were Gram-positive and three were Gram-negative bacteria isolates were isolated from avocado plant rhisosphere (B site) and also 7 isolates and 4 were Grampositive and negative bacteria isolated from the of banana rhisophere ( $\mathrm{C}$ site) respectively. Finally, 11 gram positive and 4 gram negative bacteria were isolated from Canaindica (D) plant root. As Halverson and Handelsman [6]; Parmar [7] reported, By the same token the identification of our isolates based on morphological characteristics and some biochemical tests were indicated that most dominant isolates were gram positive , rod shaped and gram negative, rod shaped of Bacillus, pseudomonas were the main starch degrading rhizobacteri a isolated from starch agar plates respectively. Various species of bacteria, fungi and Actinomycetes are most prominent enzyme producers, among various amylase producers Bacillus species are most prominent. With increase in its application spectrum, the demand is for the enzyme with specificity. This finding argeumented with the study of Sasmita M and Niranjan B $[19,20]$ states that efficiency of bacillus species to degrade starch shows high efficiency to reduce sugar in the area with factors such as temperature and $\mathrm{PH}$ value correlated. Therefore, this result is true and similar with the finding of above author.

The highest of most rhizobacteria of showing high value of starch degrading index were mostly gram positive, spore former bacteria and enzyme production from microorganism is directly correlated to the time period of incubation [21]. The highest degradation of starch by rhizobacteria can secrete amylases to the outside of their cells to carry out extra-cellular digestion and facilitate different another organic matters for plants to easily absorb and made their food $[22,23]$. According to [24] suggesting that the hydrolyzability of the substrate by amylase increased with increase of starch solubility irrespective of large diameter of the colony formed by gram negative, nonspore former rhizobacteria the calculated starch degrading index value formed range was very low in relation to gram positive rhizobacteria of low diameter colony forming this again indicate the spore forming and rod shape, Gram positive bacteria almost shows characteristics of Bacillus species and they can tolerate different factors and produce Amylase enzymes to degrade starch into soluble form and applicable to food, industrial and leathery industries (Table 4) (Figure 2).

\begin{tabular}{|c|c|c|c|}
\hline Isolate code & Diameter of colony(cm) & Diameter of clear zone(cm) & SDI of RB \\
\hline AJUMC1 & 1.5 & 2.9 & 1.933 \\
\hline AJUMC2 & 1.3 & 2.7 & 2.07 \\
\hline AJUMC3 & 1.6 & 2.5 & 1.56 \\
\hline AJUMC4 & 1.4 & 3 & 2.14 \\
\hline AJUMC5 & 1.6 & 2.8 & 1.75 \\
\hline AJUMC6 & 1 & 1.8 & 1.8 \\
\hline AJUMC7 & 1.8 & 3 & 1.66 \\
\hline AJUMC8 & 1.3 & 1.6 & 1.23 \\
\hline AJUMC9 & 1.9 & 3.3 & 1.74 \\
\hline AJUMC10 & 1.6 & 2.8 & 1.87 \\
\hline AJUMC11 & 1.5 & 2.6 & 1.73 \\
\hline AJUMC12 & 1.3 & 2.8 & 2.15 \\
\hline AJUMC13 & 2.4 & 3.6 & 1.5 \\
\hline AJUMC14 & 1.6 & 2.7 & 1.69 \\
\hline AJUMC15 & 1.6 & 2.5 & 1.56 \\
\hline AJUMC16 & 1.3 & 2.8 & 2.15 \\
\hline AJUMC17 & 1.6 & 2.4 & 1.5 \\
\hline BJUMC1 & 2.3 & 3.5 & 1.52 \\
\hline BJUMC2 & 1.75 & 2.4 & 1.37 \\
\hline BJUMC3 & 1.2 & 2 & 1.66 \\
\hline BJUMC4 & 1.5 & 2.8 & 1.86 \\
\hline BJUMC5 & 1 & 2.1 & 2.1 \\
\hline BJUMC6 & 1.2 & 1.9 & 1.58 \\
\hline BJUMC7 & 1.2 & 2.25 & 1.875 \\
\hline
\end{tabular}




\section{Open Access Journal of Microbiology \& Biotechnology}

\begin{tabular}{|c|c|c|c|}
\hline BJUMC8 & 1.7 & 2.8 & 1.64 \\
\hline BJUMC9 & 1.2 & 1.9 & 1.58 \\
\hline BJUMC10 & 0.95 & 1.7 & 1.79 \\
\hline CJUMC1 & 1.5 & 2.6 & 1.73 \\
\hline CJUMC2 & 1.4 & 2.3 & 1.64 \\
\hline CJUMC3 & 1.1 & 1.9 & 1.72 \\
\hline CJUMC4 & 1.2 & 1.8 & 1.5 \\
\hline CJUMC5 & 1.8 & 2.9 & 1.61 \\
\hline CJUMC6 & 1.25 & 2.3 & 1.84 \\
\hline CJUMC7 & 2.5 & 3.6 & 1.44 \\
\hline CJUMC8 & 1.8 & 3 & 1.67 \\
\hline CJUMC9 & 1.2 & 2.1 & 1.75 \\
\hline CJUMC10 & 1.3 & 2.3 & 1.77 \\
\hline CJUMC11 & 1.6 & 2.9 & 1.81 \\
\hline DJUMC1 & 2.5 & 3.5 & 1.4 \\
\hline DJUMC2 & 0.8 & 1.2 & 1.5 \\
\hline DJUMC3 & 0.8 & 1.4 & 1.75 \\
\hline DJUMC4 & 1.7 & 2.7 & 1.59 \\
\hline DJUMC5 & 1.2 & 2.4 & 2 \\
\hline DJUMC6 & 1.7 & 2.5 & 1.47 \\
\hline DJUMC7 & 1.1 & 1.9 & 1.72 \\
\hline DJUMC8 & 0.9 & 1.8 & 2 \\
\hline DJUMC9 & 1.8 & 2.6 & 1.44 \\
\hline DJUMC10 & 0.84 & 1.3 & 1.57 \\
\hline DJUMC11 & 2.1 & 3 & 1.4 \\
\hline DJUMC12 & 1.4 & 2.3 & 1.64 \\
\hline DJUMC13 & 1.6 & 2.6 & 1.625 \\
\hline DJUMC14 & 1.2 & 1.6 & 1.43 \\
\hline DJUMC15 & 1.4 & 2 & \\
\hline & & & \\
\hline
\end{tabular}

Table 4: Starch degrading index of isolated colonies (SDI).

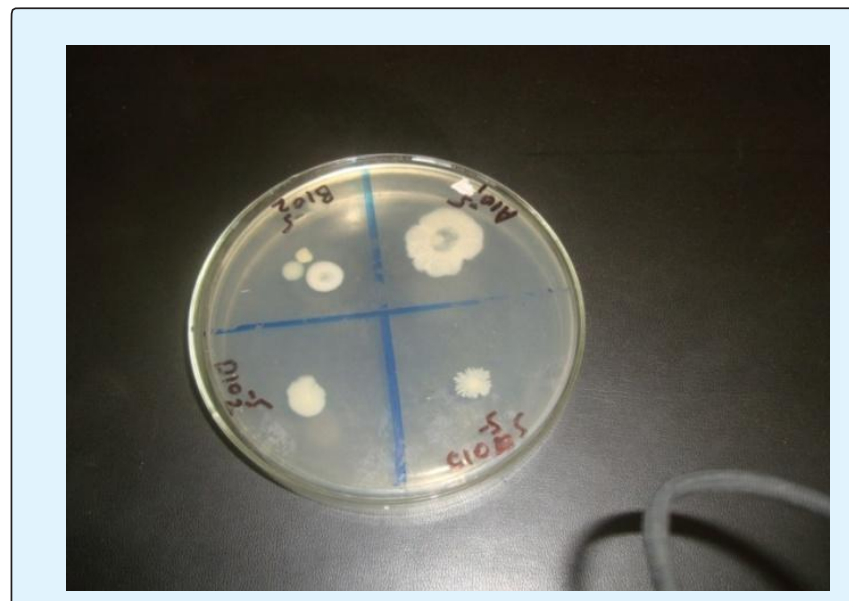

Figure 2: Amylase Activity Analysis on Petri-Dish.

The amylase production of bacteria was tested by starch hydrolysis. On the basis of the area of clearance, characterization, and high amount of amylase activity determined by Parameter $(\mathrm{pH}$, temperature, incubation period and Concentration of starch) (Table 5) from the above table all isolates response positive result for $\mathrm{PH}$ value, Temperature, concentration of starch and incubation period enhanced enzyme activity with the increase in incubation time especially true for bacillus species [25,26] (Figure 3).

\begin{tabular}{|c|c|c|c|c|}
\hline $\begin{array}{c}\text { Isolate } \\
\text { code }\end{array}$ & $\mathbf{p H}(\mathbf{7})$ & $\begin{array}{c}\text { Temperature } \\
\left(\mathbf{3 5}^{\circ} \mathbf{C}\right)\end{array}$ & $\begin{array}{c}\text { Starch } \\
\text { con.(1.5\%) }\end{array}$ & $\begin{array}{c}\text { Incubation } \\
\text { period (24h.) }\end{array}$ \\
\hline AJUMC & + & + & + & + \\
\hline BJUMC & + & + & + & + \\
\hline CJUMC & + & + & + & + \\
\hline DJUMC & + & + & + & + \\
\hline
\end{tabular}

Table 5: Determination of Different Parameter. 


\section{Open Access Journal of Microbiology \& Biotechnology}

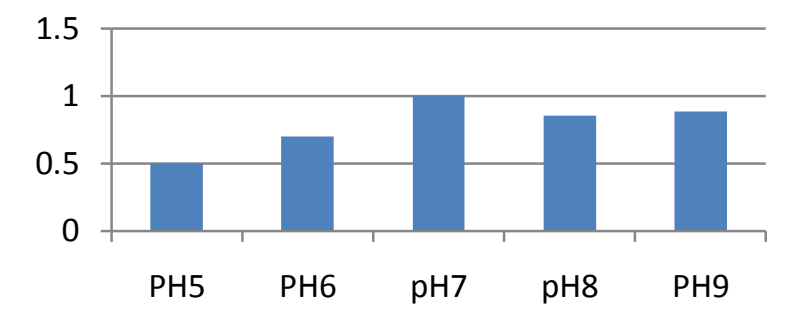

Figure 3: Amylase activity at different $\mathrm{pH}$.

While amylase activity recorded at different $\mathrm{pH}$ from 5 to 9 it shows maximum amylase activity at $\mathrm{pH} 7(1 \mathrm{U} / \mathrm{ml})$. There is increase in amylase activity at basic $\mathrm{pH} 9=0.88$ $\mathrm{U} / \mathrm{ml}$ and decrease in acidic medium $\mathrm{pH} 5=0.5 \mathrm{U} / \mathrm{ml}$. As [18] reported the enzyme showed good activity over a board range of temperatures $\left(40-80^{\circ} \mathrm{C}\right)$ and $\mathrm{pH}$ values (37 ), indicating it has potential use in a broad range of food industry applications. In mean while the result obtained correlate this statement and can be play great role industry applications. The optimum temperature and $\mathrm{pH}$ for the enzyme were $35^{\circ} \mathrm{C}$ and $\mathrm{pH} 7$, respectively. (Figure 4)

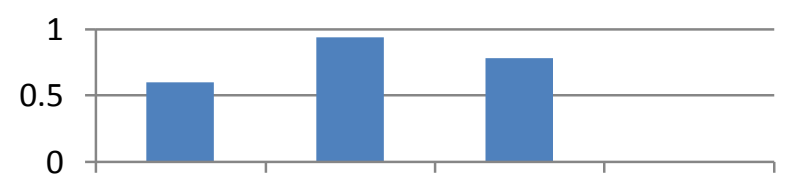

temp $30^{\circ} \mathrm{C}$ temp $35^{\circ} \mathrm{C}$ temp $40^{\circ} \mathrm{C}$

Figure 4: Amylase activity at different temperature.

Amylase activity recorded at different temperature value from lowest to highest such as at $30^{\circ} \mathrm{C}, 40^{\circ} \mathrm{C}$, and $35^{\circ} \mathrm{C}$ respectively. Therefore the species identified from this range of temperature was pseudomonas genera because of the availability or growth favors of pseudomonas species almost all survive at $35^{\circ} \mathrm{C}_{-} 40^{\circ} \mathrm{C}$. This is almost similar with the suggestion of [24] the enzyme production reached maximum at temperature of $30^{\circ} \mathrm{C}, \mathrm{pH}$ 7 , with $40 \mathrm{~g} / \mathrm{L}$ starch in the medium inoculated with $1.4 \%$ v/v spore.

\section{Conclusions}

The present study revealed that all four sites soil samples taken from Jimma University Plant root were inhabited with diverse microorganisms mostly of bacillus and pseudomonas genera with high potential to degrade starch thereby degrading starch blended material (polymers) to avoid pollution from the environment. The result from table 4 clearly indicates that the highest to lowest range of starch degrading index of rhizo bacteria capacity was found from $2.15-1.23 \mathrm{~cm}$ range. Although amylase can be acquired from many plants and animals, microbial amylase generally meets industrial demand. Amylase activity was dramatically enhanced by $\mathrm{Co}^{2+}$ addition and slightly increased by $\mathrm{Na}^{+}$and $\mathrm{Mn}^{2+}$ addition. So to increase its activity for the future addition of $\mathrm{Co}^{2+}$ is applicable. Bacterial isolate produce amylase at alkaline culture conditions and different factors greatly regulates the growth and production of amylases. The results in this study on different factors will be useful during further production of amylase by these micro organisms and the production of amylase depends on the microorganisms and the geographical area of the study design. Therefore, this is almost best result and key view for further study and commercialization. Based on the result of this study, further study must be carried out using a molecular identification system [27].

\section{References}

1. Berendsen RL, Pieterse C, Bakker P (2012) The rhizosphere microbiome and plant health. Trends Plant Sci 17(8): 478-486.

2. Kennedy AC (2005) Rhizosphere. In: Sylvia DM, et al. (Eds.), Principles and applications of soil microbiology, $2^{\text {nd }}(E d n)$, Pearson, Prentice Hall, Upper Saddle River, NJ, pp: 242-262.

3. Ahmad M, Kibret M (2014) Mechanisms and applications of plant growth promoting rhizobacteria: current perspective. Journal of King Saud University Science 26(1): 1-20.

4. Hayat R, Ali S, Amara U, Khalid R, Ahmed I (2010) Soil beneficial bacteria and their role in plant growth promotion: a review. Annals of Microbiology 60(4): 579-598.

5. Kloepper JW (2003) A review of mechanisms for plant growth promotion by PGPR. In 6th international PGPR workshop 10: 5-10.

6. Halverson LJ, Handelsman J (1991) Enhancement of soybean nodulation by Bacillus cereus UW85 in the field and in a growth chamber. Appl Environ Microbiol 57(9): 2767-2770. 


\section{Open Access Journal of Microbiology \& Biotechnology}

7. Parmar N, Dadarwal KR (1999) Stimulation of nitrogen fixation and induction of flavonoids like Compounds by rhizobacteria. Journal of applied Microbiology 86(1): 36-44.

8. Leja K, Lewandowicz G (2010) Polymer Biodegradation and Biodegradable Polymers. Polish J of Environ Stud 19(2): 256-266.

9. Chandra R, Rustgi R (1998) Biodegrable polymers, propagation of Polymer science 23: 1273-1335.

10. Aiba S, Kitai K, Imanaka $T$ (1983) Cloning and Expression of Thermo stable $\alpha$-Amylase Gene from Bacillus stearothermophilus in Bacillus stearothermophilus and Bacillus subtilis. Appl Environ Microbiol 46(5): 1059-1065.

11. Tonkova A, Manolov R, Dobreva E (1993) Thermo stable $\alpha$-amylase from derepressed Bacillus lichenformis produced in high yields from glucose. Process Biochemistry 28(8): 539-542.

12. Kathiresan K, Manivannan S (2006) $\alpha$-amylase production by Penicillium fellutanum isolated from mangrove rhizospheric soil. African journal of Biotechnology 5(10): 829-832.

13. Mishra S, Behera N (2008) Amylase activity of a starch degrading bacteria isolated from soil receiving kitchen wastes. African Journal of Biotechnology 7(18):1-3.

14. Zhi-fen W, Lin F, Ke-xi Z, Xin F (2008) Application and research progress of starch in polymer Materials. Journal of Clinical Rehabilitative tissue Engineering Research 12(19): 3789-3790.

15. Smith AM (2001) The biosynthesis of starch granules. Biomacromolecules 2(2): 335-341.

16. Vanderzee MZ (1997) Structure-Biodegradability Relationships of Polymeric Materials. Wageningen University \& Research 1(1): 256-259.

17. Alemu A, Tsegaye W, Golassa L, Abebe G (2011) Urban malaria and associated risk factors injimma town, south-west Ethiopia. Malaria Journal 10: 173200.

18. Oseni O, Ekperigin M (2013) Isolation and activity of alpha amylase from selected bacteria strains in the forest soil. Global journal of bioscience and technology 2(1): 17-20.

19. Sasmita M, Niranjan B (2008) Amylase activity of a starch degrading bacteria isolated from soil receiving kitchen wastes. African Journal of Biotechnology 7(18): 3326-3331.

20. Alariya SS, Sethi S, Gupta S, Lal GB (2013) Amylase activity of a starch degrading bacteria isolated from soil. Archives of applied science Research 5(1):15-24.

21. Smitt JP, Rinzema J, Tramper H, Van M, Knol W (1996) Solid state fermentation of wheat bran by Trichoderma reesei QMQ414: substrate composition changes, $\mathrm{C}$ balance, enzyme production, growth and kinetics. Applied Microbial Biotechnology 46(5-6): 489-496.

22. Cordeiro CAM, Martinas MLL, Lucaino A (2003) Production and Properties of alpha amylase from thermophylic Bacillus specie. Brazil Journal of Microbiology 33(1):57-61.

23. Nath L, Singh AV, Singh A (2010) Pharmaceutical, food and non-food application of modified starch. Journal of Environmental agricultural and food chemistry 9(7): 1214-1221.

24. Wang S, Lin C, Liu Y, Shen Z, Jeyaseelan J, et al. (2016) Characterization of a starch-hydrolyzing $\alpha$-amylase produced by Aspergillus niger WLB42 mutated by ethyl methanesulfonate treatment. Int J Biochem Mol Biol 7(1):1-10.

25. Aiyer PV (2004) Effect of Carbon and Nitrogen ratio on alpha amylase production by Bacillus licheniformis SPT 27. African Journal of Biotechnology 3(10): 519522.

26. Ha YM, Lee DG, Yoon JH, Park YH, Kim YJ (2001) Rapid and simple purification of a novel extracellular $\beta$-amylase from Bacillus sp. Biotechnology letters 23(17): 1435-1438.

27. Zehra B, Nadeem U, Solangi BA (2011) Utilization of Starch in Leather Processing an EnvironmentFriendly Polymer Science, Technology \& Development 30(2): 12-13. 